\title{
On McDowell's identity conception of truth
}

\author{
William Fish \& Cynthia Macdonald
}

Julian Dodd (1995) has argued that John McDowell's position on the relation between mind and world is committed to not one but two identity theories of truth, which McDowell conflates with one another and whose combination is incoherent. According to one ('robust') theory, a proposition is true if and only if it is identical with a fact, where 'facts' are to be understood as 'item[s] with particular objects and properties as constituents whose totality makes up the world' (1995: 161). This conception, Dodd tells us, would allow McDowell to realize his goal of eliminating any gap between content and reality. According to the other ('truistic') Fregean conception, a fact just is a true Thought 'rather than an occupant of the world' (1995: 161-62), because its constituents are Fregean senses rather than objects and properties. On this identity theory, a Thought is true if and only if it is identical with a fact. This conception of facts would allow McDowell to realize the goal of holding a merely truistic position. But Dodd claims that by conflating these two theories, McDowell ends up holding an incoherent position - incoherent because, if it has anything to say about the relation between mind and world, it is that the world is made up of Thoughts.

Although Dodd's verdict has recently been echoed with approval by Christian Suhm, Philip Wagemann and Florian Wessels (Suhm et al. 1999) and Pascal Engel (Engel 2001, 2005), we think that these discussions fail to engage with the kind of position that McDowell holds, and so miss their target entirely. We also think, however, that McDowell's more recent work does not make it any easier than his earlier work to see how it could be the case that a Thought is true if and only if it is identical with a fact, 
understood as a constituent of the world. The present paper offers an explanation of how this could indeed be the case.

Dodd's objection takes, as a starting point, a collection of passages in Mind and World in which McDowell appears to articulate first the robust, ${ }^{1}$ then the truistic, ${ }^{2}$ identity theory. On the basis of these passages, Dodd argues that McDowell is committed to a position on which facts are, at the same time, both worldly items and Fregean senses. But he, and others following him, argue that such an identity must be misconceived:

... facts (if worldly) and [Fregean] Thoughts are in quite different categories, and so the identification cannot be made good. And it is no use saying that senses just are objects and properties. Senses are modes of presentation of objects and properties; they cannot be identified with them. (Dodd 1995: 163; see also Suhm et al. 1999: 30)

... thoughts are senses, and presumably facts, if they belonged to the world, would be located within the world of references. (Engel 2001: 443)

Yet in subsequent discussions, McDowell reasserts the very identity claim these theorists argue to be incoherent. For example, in response to Suhm et al., he repeats his endorsement of the view that facts are 'Fregean senses, with Fregean senses as their constituents' (1999: 93) before reiterating the claim that 'objects figure in the world by figuring in facts' (1999: 94). In his response to Engel, McDowell is even more explicit. He rejects Engel's claim that worldly facts do not belong on the level of sense as 'simply wrong. 'Facts', he says,

particular things that are the case, belong to the world conceived as everything that is the case. But something that is the case is (is nothing

${ }^{1}$ An example in the case of thought contents is the claim that

there is no ontological gap between the sort of thing one can ... think, and the sort of thing that can be the case. When one thinks truly, what one thinks is the case. So since the world is everything that is the case ..., there is no gap between thought, as such, and the world. (McDowell 1994: 27)

In the case of perceptual content:

That things are thus and so is the ... content of an experience, but if the subject of experience is not misled, that very same thing, that things are thus and so, is also a perceptible fact, an aspect of the perceptible world. (McDowell 1994: 26)

2 Thus,

... to say that there is no gap between thought, as such, and the world is just to dress up a truism in high-flown language. All the point comes to is that one can think, for instance, that spring has begun, and that the very same thing, that spring has begun, can be the case. (McDowell 1994: 27) 
other than) something that can be thought, and as such it is located in the realm of sense. (McDowell 2005: 84)

So it appears that Dodd is right: McDowell is indeed committed to a conception of facts according to which facts are both senses and constituents of the world. The trick, though, lies in seeing how such a position can avoid the charge of incoherence.

Note first that while McDowell does endorse the claim that facts are constituents of the world, he does not do so by endorsing the robust conception of facts as characterized by Dodd. He says:

[Dodd] thinks that for facts to seem capable of being constituents of the world ... they would need to have as their constituents objects and their properties, ... [but] I see no justification for this. (McDowell 1999: 93-4)

How, then, should we understand the claim that facts are constituents of the world? Later, McDowell tells us that a fact is 'an element of the world, on the natural Tractarian conception' (1999: 96). ${ }^{3}$ So when McDowell holds that facts are both senses and constituents of the world, he endorses a position according to which facts are, at the same time, both Tractarian and Fregean.

Now, McDowell's endorsement of the Fregean view - that facts are Fregean senses, with Fregean senses as their constituents - suggests a picture in which there are two kinds of Fregean senses: compound senses which have other senses as constituents and other, uncompounded, constituent senses. Elsewhere, he calls these rudimentary senses 'concepts' (e.g. 1984/1998: 218). What is more, he claims that

the content of a whole thought must do more than present what one is thinking about in a certain way (for instance in the way in which 'that tiger', in the circumstances I am imagining [i.e., in the presence of a suitably situated tiger], presents a certain tiger); it must also fix how one thinks things stand with what one is thinking about (for instance that it looks undernourished). (2005: correspondence)

This suggests that, for a Fregean sense to be of sufficient complexity to be the content of a whole thought, it must be the kind of compound Fregean sense which is constituted by concepts.

3 As we understand it, the distinction between the Tractarian and robust conceptions of fact is one of ontological priority. According to the robust conception, the basic ontological elements of the world are objects and properties; facts on the other hand, are ontologically derivative - cases of objects bearing properties. The Tractarian conception reverses this order of explanation; for the Tractarian, facts are the basic ontological elements of the world. Objects and properties are the derivative ontological class. 
With this in mind, note that, in the Tractatus, Wittgenstein also distinguishes between those facts which are simple, uncompounded facts and facts which are themselves constituted out of other facts. As Russell explains in his Introduction to the text, 'Facts which are not compounded of other facts are what $\mathrm{Mr}$ Wittgenstein calls Sacherverhalte, whereas a fact which may consist of two or more facts is called a Tatsache' (1961/ 2001: xi). ${ }^{4}$ Our suggestion is that we can only appreciate McDowell's position if we see him as aligning the two conceptions of facts, the Fregean one and the Tractarian one, so as to commit to the following identity claims: (1) that in those cases in which we are not misled, the Fregean fact - the compound Fregean sense which is of sufficient complexity to function as the content of a whole thought - is identical to a particular compound Tractarian fact or Tatsache, and (2) that the concepts which constitute the compound Fregean sense are identical to the constituents of the Tatsache: the basic uncompounded facts or Sacherverhalte. ${ }^{5}$

If this is indeed how to understand McDowell's identity claim, we can now see how facts, conceived of as constituents of the world, might at the same time be modes of presentation of objects. Consider the true content/ fact that $<$ that tiger is undernourished $>$. Qua compound Tractarian fact/ Tatsache, this is constituted by Sacherverhalte: but what might the basic constituents of this fact be? Our suggestion is that the Sacherverhalte which constitute this Tatsache are (a) the fact of the object's being a tiger, and (b) the fact of the object's being undernourished. If Sacherverhalte such as these were to be identified with the concepts which constitute

${ }^{4}$ In fact, as Russell goes on to make clear, this distinction is not as mutually exclusive as this may suggest: anything which qualifies as a Sacherverhalt will also qualify as a Tatsache. So strictly speaking, what we find is a term used to apply to all facts, simple and compound (Tatsache) and a term which only applies to the simple, uncompounded basic facts (Sacherverhalte). However, to keep the ensuing discussions as clear as possible, we will use the terms as if they were as mutually exclusive as the Russell quotation suggests.

5 Senses, thus understood, would not exist if the object they present did not exist they would be what McDowell calls de re senses (1984/1998). This would of course entail that such senses would be unavailable to feature in the contents of false thoughts, but McDowell repeatedly insists that this positive proposal is only supposed to pertain to those cases in which we are not misled. When he (briefly) discusses the possibility of misleading experience (1994: 113), he refers us to two papers in which he endorses disjunctivism, an approach to such matters which allows that we can tell different stories about veridical and non-veridical cases that are indistinguishable from the subject's point of view. So we should be wary of assuming that McDowell is committed to an explanation of the same broad kind in the misleading cases - involving, say, a realm of objective non-facts (Dodd 1995: 163; see also Engel 2001: 444). As to what positive story McDowell might offer, he says little on this here and for us to say more would take us well beyond the scope of the present paper. 
compound Fregean senses, we could begin to see just how a Tractarian fact might also be a mode of presentation of an object. Both of the Sacherverhalte just mentioned could be seen to present an object in a certain way: the first - the fact of the object's being a tiger - presents the object in a certain way, as being a tiger; the second - the fact of the object's being undernourished - presents the object as being undernourished. These are at the same time both Tractarian facts (albeit a particular class of Tractarian fact - the uncompounded Sacherverhalte) and modes of presentation of objects (concepts/simple Fregean senses). ${ }^{6}$

Notice how this interpretation of McDowell's alignment of the two conceptions of facts enables us to make sense of his claims that the resultant position is consistent with common-sense metaphysical realism (1999: 94), and that 'objects themselves can figure in thoughts that are among the contents of the mind' (1986/1998: 237). When it comes to the metaphysical claim, McDowell agrees that his theory would be unacceptable if it entailed that 'there were no satisfactory way to see objects as, in some sense, figuring in the world so conceived' but points out that, on this picture, 'objects figure in the world by figuring in facts' (1999: 94). If Sacherverhalte are indeed as we have suggested, it is plain to see how objects can be said to figure in such facts and thereby figure in the world.

As for the epistemological claim, McDowell insists that we must distinguish the assertion that an object figures in content from the assertion that an object is a constituent of content (1986/1998: 237). The reason for this is clear: we need to distinguish between what one thinks, a Fregean Thought or thinkable, and what one thinks about, when one thinks what one thinks. And once we understand this, we are explicitly prohibited from reading the claim that objects 'figure in' thoughts in the Russellian way on which objects are literally the constituents of thoughts because we don't think objects, we think about them. We therefore need an alternative way of understanding how objects 'figure in' the contents of thoughts, and this is provided by the interpretation we have been recommending: if the conceptual constituents of the contents of true thoughts are, as we have suggested, Sacherverhalte, objects will 'figure in' thoughts by figuring in the Sacherverhalte that constitute the contents of those thoughts as just described. Thus, McDowell says,

6 This explains how a fact could be a mode of presentation of an object; what about modes of presentation of properties? On this question, McDowell says that

A repertoire of concepts of ways of being colored ... already contains the conceptual content for a repertoire of concepts of associated objects - colors ... One carves out, as it were, a concept of a color, an object of a certain kind, by imposing a different articulation on a thought that first comes into view as a thought to the effect that an ordinary object is colored in a certain way. (1998: 416) 
Of course, we also need to connect what can be said at the level of sense to what can be said at the level of reference. But there is no problem about doing that. There is no problem about what the world conceived as everything that is the case, and so as belonging to the realm of sense, has to do with the world on that other possible conception, the realm of reference. Engel, for instance, is thought about by anyone who thinks that Engel is unimpressed by the identity theory of truth. (2005: 84-5)

This is how he aims to resist the idea that, even in the cases where things go well, there remains a 'gap' between mind and world. When our thoughts are true and experiences veridical, there is simply no scope for there to be such a gap as, in such cases, the constituents of the contents of experience and judgment will simply be the basic ingredients of the world.

\author{
Massey University \\ Palmerston North, New Zealand \\ W.J.Fish@massey.ac.nz
}

Queen's University Belfast

Belfast BT7 1PA, Northern Ireland, UK

c.macdonald@qub.ac.uk

\title{
References
}

Dodd, J. 1995. McDowell and identity theories of truth. Analysis 55: 160-65.

Engel, P. 2001. The false modesty of the identity theory of truth. International Journal of Philosophical Studies 9: 441-58.

Engel, P. 2005. The unimportance of being modest: a footnote to McDowell's note. International Journal of Philosophical Studies 13:1: 89-93.

McDowell, J. 1994. Mind and World. Cambridge Mass.: Harvard University Press.

McDowell, J. 1984/1998. De re senses. Reprinted in his Meaning, Knowledge and Reality, 1998: 214-27. Cambridge Mass.: Harvard University Press.

McDowell, J. 1986/1998. Singular thought and the extent of inner space. Repr. in his Meaning, Knowledge and Reality, 1998: 228-59. Cambridge, Mass.: Harvard University Press.

McDowell, J. 1998. Response to Peacocke. Philosophy and Phenomenological Research 58: 414-99.

McDowell, J. 1999. Responses. In John McDowell: Reason and Nature, ed. M. Willaschek, 91-114. Münster: LIT Verlag.

McDowell, J. 2005. The true modesty of an identity conception of truth: a reply to Pascal Engel (2001). International Journal of Philosophical Studies 13: 83-88.

Suhm, C., P. Wagemann and F. Wessels. 1999. Ontological troubles with facts and objects in McDowell's Mind and World. In John McDowell: Reason and Nature, ed. M. Willaschek, 27-33. Münster: LIT Verlag.

Wittgenstein, L. 1961/2001. Tractatus Logico-Philosophicus. Trans. D. F. Pears and B. F. McGuinness. London: Routledge. 